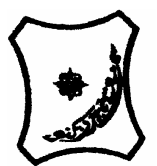

Bayero Journal of Pure and Applied Sciences, 8(2): 156-165

Received: November, 2015

Accepted: December, 2015

ISSN $2006-6996$

\title{
ZOOPLANKTON AS BIOINDICATORS OFWATER QUALITY IN JAKARA DAM, KANO STATE, NIGERIA
}

\author{
Abubakar, A. and Abdullahi, B.A. \\ Department of Biological Science, Bayero University, Kano. \\ Corresponding Author: Email:abdulrahmanabubakar96@yahoo.com
}

ABSTRACT

The study of zooplankton as bioindicators of water quality in Jakara Dam was carried out for a period of 12 months (March,2013-February 2014). Zooplankton and water samples were collected and analyzed using standard methods. Sampling sites designated as $A, B, C, D$, and $E$ were chosen. Result of physico-chemical parameters analysed showed that temperature, secchi disk transparency, pH and electrical conductivity ranged between 25.3-23.9, $10.7-57.9 \mathrm{~cm}, 7.9-7.7$ and $856.7-817.9 \mu 5 / \mathrm{cm}$ respectively, so also dissolved oxygen, biochemical oxygen demand, nitrate and phosphate ranged between 4.5-3.3 mg/l, 2.5-1.7 mg/l, 23.8-14.3 mg/l, and 15.8-12.5mg/l respectively. Among the zooplankton, Rotifers were the dominant, contributing $27.10 \%$ of the total fauna composition. Cladocerans constituted 26.99\%, Cyclopoida 16.15\%, Calanoida 15.08\%, and Protozoans $14.68 \%$. However, a combined total of 36 zooplankton species were encountered, Rotifers had 10, Cladocerans 10, Cyclopoida 6, Protozoans 6, and Calanoida 4. The total fauna composition recorded was 2606.58 Org/I with the highest zooplankton density recorded at site D (631.64 Org/I) and lowest at site $A$ (384.31 Org/I). Bosmina longirostris had the highest total species count of 250.88 Org/l while Afrocyclops monodi had 7.02 Org/l. Rotifers are signs of deteriorating condition of the water quality. Pearson's correlation existed between zooplankton, nitrate, phosphate and electrical conductivity at P<0.01. During the period of this study, site A had low secchi disk transparency, high level of nitrate and phosphate. This is due to human activities taking place at the site.In a bid to providing safe water for domestic and industrial uses, water treatment plant should be provided to help in water treatment especially at site $A$ (Bela community) of this research area.

Key words: Bela community, Deteriorating, Zooplankton, Water Quality, Jakara Dam

\section{INTRODUCTION}

The use of living organisms to determine the presence, amounts, changes in and effects of physical, chemical, and biotic factors in the environment is termed biological monitoring (Baker,1976). Biological monitoring is a valuable method used in conservation studies to protect natural ecosystems, which include preservative measures. Bioindicators of pollutants are useful in predicting the level and degree of pollutants before the effect of the pollutant starts. Study of these organisms is generally linked to the use of mathematical distribution of these organisms in a community to which bioindicator species belong (Singh and Singh, 2002). Imam (2011) studied the state of Jakara-Getsi River system in terms of zooplanktonic fauna composition and distribution. He observed bimodal fluctuation in zooplankton density. However, despite the numerous works carried out in the study of zooplankton fauna composition, it is still desirable to carry out more of such study due to global environmental changes that may lead to appearance and disappearance of some species in the area.

This study was aimed at investigating the species composition of zooplankton to the existing water quality in Jakara Dam and their seasonal fluctuation. It also studied nitrate and phosphate in addition to the physicochemical parameters studied by Imam (2011).

\section{MATERIALS AND METHODS}

Study Area: Jakara Dam

Jakara Dam was constructed in 1976 and situated in Minjibir Local Government Area in North - Eastern part of Kano metropolis about $41.5 \mathrm{~km}$ from Kano city centre (Duwa and Oyeyi 2009). The Dam was constructed for irrigation, recreation and wildlife conservation. The reservoir was designed to contain 54.34 million cubic metres of water with surface area of 1,659 ha (WRECA, 1974). The maximum depth of the dam was 14.3 metres (Ministry of Water Resources Kano State). Study has shown that the river system is highly contaminated with both organic and inorganic pollutants (Imam, 2010).

Sampling Sites

Five sampling sites selected for this study were based on differences in their anthropological condition ( Figure 1). GPS 12 model (GARMIN, USA) was used in marking the global position of the site. Depth measurements were done using graduated lines (Welcomme, 1985). 
SITE A: This site is located on latitude $12^{\circ} 08^{\prime} 49.29^{\prime \prime} \mathrm{N}$ and longitude $8^{\circ} 41^{\prime} 19.40^{\prime \prime} \mathrm{E}$, the inlets where irrigation farming, fishing and human activities are taking place with mean depth of $1.2 \mathrm{~m}$.

SITE B: This is located on latitude $12^{\circ} 08^{\prime} 36.46^{\prime \prime} \mathrm{N}$ and longitude $8^{\circ} 41^{\prime} 44.84^{\prime \prime} \mathrm{E}$, the midpoint of the water with mean depth of $8.6 \mathrm{~m}$.
SITE C: This is located on latitude $12^{\circ} 08^{\prime} 35.86^{\prime \prime} \mathrm{N}$ and longitude $8^{\circ} 41^{\prime} 15.84^{\prime \prime} \mathrm{E}$, the mid point of the water with mean depth of $7.4 \mathrm{~m}$

SITE D: This is located on latitude $12^{\circ} 08^{\prime} 41.26^{\prime \prime} \mathrm{N}$ and longitude $8^{\circ} 41^{\prime} 24.54^{\prime \prime} \mathrm{E}$, where irrigation farming is taking place with mean depth of $5.0 \mathrm{~m}$.

SITE E: This is located on latitude $12^{\circ} 08^{\prime} 27.97^{\prime} \mathrm{N}$ and longitude $8^{\circ} 41^{\prime} 11.98^{\prime \prime} \mathrm{E}$, the outlets with mean depth of $2.3 \mathrm{~m}$.

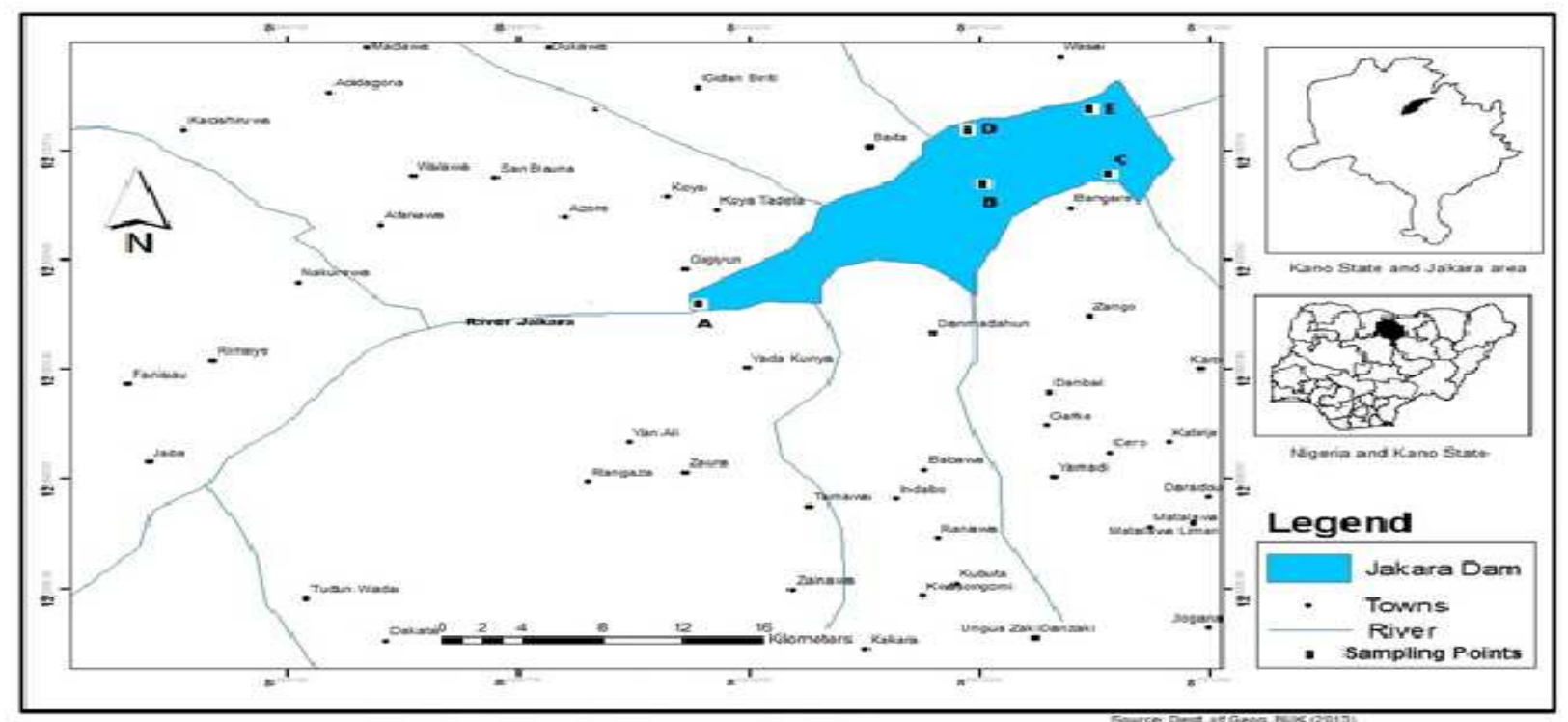

Figure 1: Map of Jakara Dam Showing Sampling Sites Physical Analyses of Water Samples

\section{Measurement of Temperature}

This was determined using mercury- in -glass thermometer, by dipping it into the water and allowed to stabilize for 5 seconds, removed and reading recorded immediately (APHA, 2005).

\section{Determination of Transparency}

Water transparency was determined using secchi disk with black and white paints. The disk was lowered until it disappeared from view and the depth recorded. The disk was raised until it just appeared and the depth was recorded. The disk visibility was estimated by taking the average of the two readings while viewing the disc directly from above and backing the sun (Abdullahi, 1990). The depth at which it disappeared in the water ( ${ }_{1}$ ) and reappeared (2) were noted. The transparency of the water body was computed as follows:

Transparency (Secchi Disk Transparency) $=\frac{\left(x+x_{2}\right)}{2}$ Where;

1 = Depth at which Secchi disk disappeared.

${ }_{2}=$ Depth at which Secchi disk reappeared.

Determination of Electrical Conductivity

Conductivity was measured using conductivity meter with model HI 76310 manufactured by Hanna (APHA, 2005).

\section{Determination of $\mathbf{p H}$}

The $\mathrm{pH}$ values were obtained using a digital $\mathrm{pH}$ meter model HI 1131 manufactured by Hanna (APHA, 2005).

\section{Chemical Analyses}

\section{Determination of Dissolved Oxygen}

The sample of the water was treated with manganous chloride tetrahydrate $\left(\mathrm{MnCl}_{2} .4 \mathrm{H}_{2} \mathrm{O}\right)$, potassium iodine (KI) and potassium hydroxide $(\mathrm{KOH})$ under highly alkaline condition.One hundred and twenty five millilitre $(125 \mathrm{ml})$ of the water sample was measured into BOD bottles. Two millitre $(2 \mathrm{ml})$ of manganous chloride was added. [Fifty gram $(50 \mathrm{~g})$ of manganous chloride tetrahydrate was dissolved into a volume of $100 \mathrm{ml}$ of distilled water and $2 \mathrm{ml}$ of Winklers reagent $(100 \mathrm{~g}$ of $\mathrm{KOH}$ was dissolved in $20 \mathrm{ml}$ of distilled water, $60 \mathrm{~g}$ of (KI) was added and cooled. The solution was diluted to $500 \mathrm{ml}$ mark]. They were carefully added in order to prevent air bubbles at the site. All the solution was carefully inverted several times after closing it tightly. The precipitate was allowed to settle and mixed again. Two millitre $(2 \mathrm{ml})$ of concentrated sulphuric acid was added with a measuring pipette stopper. The bottle was inverted several times to dissolve the precipitate. Ten millitres $(10 \mathrm{ml})$ of the treated sample was measured into $250 \mathrm{ml}$ beaker and titrated against standard sodium thiosulphate solution $\left(\mathrm{Na}_{2} \mathrm{~S}_{2} \mathrm{O}_{2}\right.$. $5 \mathrm{H}_{2} \mathrm{O}$ ). [Three point one gram (3.1g) of $\mathrm{Na}_{2} \mathrm{~S}_{2} \mathrm{O}_{2} \cdot 5 \mathrm{H}_{2} \mathrm{O}$ was dissolved in distilled water and then made to $1000 \mathrm{ml}$ mark]. The end point was marked by a pale stew colour.

Four (4) drops of starch indicator are added and titrated until the colour disappeared and the total volume of sodium thiosulphate was recorded as 
described by Bryan (1974).

$$
\mathrm{DO}(\mathrm{mg} / \mathrm{L})=\frac{\text { ml of titrants } x(\mathrm{~N}) X 8 \times 1000}{\text { sample volume in } \mathrm{ml}}
$$

$\mathrm{Na}_{2} \mathrm{~S}_{2} \mathrm{O}_{2} \cdot 5 \mathrm{H}_{2} \mathrm{O}$ and $\mathrm{N} / 8=0.0125$.

\section{Determination of Biochemical Oxygen Demand}

This was done by incubating the bottles with the water samples at room temperature (25) for 5 days. Then DO was measured again. $\mathrm{BOD}_{5}$ was obtained by subtracting the 5 days $D O$ reading from the 0 - day reading (APHA,2005). The $\mathrm{BOD}_{5}$ was expressed in milligram per litre of DO using the following equation. $\mathrm{BOD}_{5}(\mathrm{mg} / \mathrm{L})=\mathrm{DO}(0$-day $)(\mathrm{mg} / \mathrm{L})$ initial $-\mathrm{DO}(5$-day $)$ $(\mathrm{mg} / \mathrm{L})$

\section{Determination of Nitrate}

Ten millilitre $(10 \mathrm{ml})$ of the sample was added into distillation tubes and $10 \mathrm{ml}$ of $40 \%$ sodium hydroxide $(\mathrm{NaOH})$ was also added into the distillation tube. One gram $(1 \mathrm{~g})$ of devardas alloy power was added into the distillation tube. Ten millilitre $(10 \mathrm{ml})$ of $2 \%$ boric acid was placed into a conical flask and 5 drops of mixed indicator (Methyl red $10 \mathrm{~g} \mathrm{1-1}$ and bromocresol green in 95\% ethyl alcohol) was added. Distillation starts when the steam coming from the kjadahl flask and $50 \mathrm{ml}$ of the distillate was collected in the conical flask containing $2 \%$ boric acid. The content was titrated against $0.025 \mathrm{~mol}-\mathrm{I}$ standard solution of $\mathrm{H}_{2} \mathrm{SO}_{4}$.

Calculation

$\mathrm{NO}_{3}^{-}=\frac{0.014 \times 0.025 X 100 X \text { titrants }}{A . T}$

Where:

A.T $=$ Aliquot taken $=10 \mathrm{ml}$

To convert \% into $\mathrm{mg} / \mathrm{l}$ the values obtained was multiplied by 10000 .

\section{Determination of Phosphate}

Five milliliter $(5 \mathrm{ml})$ of a clear sample was added into $50 \mathrm{ml}$ Erlenmeyer flask, $20 \mathrm{ml}$ of distilled water was added into the flask. Eight millilitre $(8 \mathrm{ml})$ of ascorbic acid molybdate was added into the sample and distillated water was added up to $50 \mathrm{ml}$ mark. Zero point two $(0.2), 0.4,0.6,0.8$ and $1 \mathrm{ml}$ of standard potassium dihydrogen phosphate $\left(\mathrm{KH}_{2} \mathrm{PO}_{4}\right)$ was diluted into $1,2,3,4$, and $5 \mathrm{ml}$ of distillated waterrespectively in $50 \mathrm{ml}$ Erlenmeyer flask.Eight millilitres $(8 \mathrm{ml})$ of colour developer (ethanoate) was then added into each and made up to $50 \mathrm{ml}$ mark. Both standard and the sample were measured after 5minutes spectrophotometrically at $690 \mathrm{~nm}$ wavelength. The concentration of the sample was estimated from the calibration curve.

Calculation

Phosphorus $\mathrm{mg} / \mathrm{L}=$

$\frac{\text { sample absorbance }}{\text { slope }} X \mathrm{Vol}$. of extract

To convert phosphorus to phosphate $\left(\mathrm{PO}_{4}^{-3}\right)$ (Orthophosphate) the values obtained was multiplied by 2.291 .

\section{BIOLOGICAL ANALYSIS OF WATER SAMPLE Collection of zooplankton}

Zooplankton were collected by using plankton net of $27 \mathrm{~cm}$ in diameter and $70 \mu$ mesh-sized with a small plastic bottle container of $20 \mathrm{ml}$ attached to it narrow end. The net was tied to a metal rod, towed horizontally for a fixed distance of 1metre, hauled out of water. The water (containing plankton) was collected in the plastic bottle at the end of the net was emptied into plastic bottle of $20 \mathrm{ml}$ and immediately fixed with $4 \mathrm{ml}$ of $4 \%$ formalin to preserved the zooplankton (Goswani,2004). Five samples were collected at each sampling site in the early hours of the morning (8.00am - 11.00am) for a period of twelve months (Abdullahi, 1990).

\section{Plankton Identification and Enumeration}

Two (2) of the five (5) samples collected at each of the sampling site were analyzed immediately while the other three (3) samples were allowed to settle for 48 hours, the average was used (Abdullahi, 1990). Each sample was homogenized after decanting $2 / 3$ of it. One mililitre of the concentrated sample was taken using pipette dropped onto a watch glass and picked with a dropper on a glass slide and viewed under a compound microscope and viewed using $\times 40$ and $\times 10$ objectives for identification (Goswani, 2004).

\section{Counting}

The species were directly counted under microscope. The Zooplankton were identified based on taxonomical classification to species level using the identification keys by Scourfield and Harding (1958), Durand and Lèvèque (1980), Shield and Green (1995), Lynne(2004).

\section{Volume of water filtered}

The volume of water that passed through the net was then estimated by using the following formula:

$V=\pi r^{2} \mathrm{~d}$

Where:

$\mathrm{V}=$ volume of water filtered.

$r=$ radius of the mouth of the net.

$\mathrm{d}=$ length of the haul.

Relative abundance was calculated as the number of individuals per litre of water filtered through the net.

\section{Org/L = \\ Total count of the specimens (average count)} volume of water filtered

\section{Statistical Analysis}

Pearson's Product Moment Coefficient Correlation was carried out to determine the relationship between the physicochemical parameters, phytoplankton and zooplankton density using Statistical Package for Social Sciences (SPSS) version 20 (Lead Technology, 2002). Biodiversity was calculated using Shannon-Weiner $(H)$, Evenness index (E), and Simpson's (Ds) Indices. 
Table 1: Zooplankton Abundance and Distribution in Jakara Dam (March 2013, - February, 2014)

\begin{tabular}{|c|c|c|c|c|c|c|c|c|c|c|c|c|}
\hline \multirow[t]{2}{*}{ Site /Species } & \multicolumn{2}{|c|}{$\mathbf{A}$} & \multicolumn{2}{|r|}{ B } & \multicolumn{2}{|c|}{ C } & \multicolumn{2}{|r|}{ D } & \multicolumn{2}{|c|}{$\mathbf{E}$} & \multirow[b]{2}{*}{$\begin{array}{l}\text { TFC } \\
\text { (Org/I) }\end{array}$} & \multirow[b]{2}{*}{$\begin{array}{l}\text { Frequency } \\
(\%)\end{array}$} \\
\hline & TC & $\begin{array}{l}\text { FC } \\
\text { (Org/I) }\end{array}$ & TC & $\begin{array}{l}\text { FC } \\
\text { (Org/I) }\end{array}$ & TC & $\begin{array}{l}\text { FC } \\
\text { (Org/I) }\end{array}$ & TC & $\begin{array}{l}\text { FC } \\
\text { (Org/I) }\end{array}$ & TC & $\begin{array}{l}\text { FC } \\
\text { (Org/I) }\end{array}$ & & \\
\hline \multicolumn{13}{|l|}{ Protozoa } \\
\hline Euglena spp. & 2.4 & 42.11 & 1 & 17.54 & 0.8 & 14.04 & 2 & 35.09 & 1.6 & 28.07 & 136.85 & 5.25 \\
\hline Paramecium spp. & 2.2 & 38.60 & 0.4 & 7.02 & 0.2 & 3.51 & 2 & 35.09 & 1.4 & 24.56 & 108.78 & 4.17 \\
\hline Stentor caudatus & 0.2 & 3.51 & 0.2 & 3.51 & 0.2 & 3.51 & 0.2 & 3.51 & 0.6 & 10.53 & 24.57 & 0.94 \\
\hline Euplotes spp. & 0.4 & 7.02 & 0 & 0.00 & 0.6 & 10.53 & 0.2 & 3.51 & 0 & 0.00 & 21.06 & 0.81 \\
\hline Vorticella spp. & 0.8 & 14.04 & 0.8 & 14.04 & 0.4 & 7.02 & 0.8 & 14.04 & 0.4 & 7.02 & 56.16 & 2.15 \\
\hline \multirow[t]{2}{*}{ Prorodon spp. } & 0.4 & 7.02 & 0.4 & 7.02 & 0.2 & 3.51 & 0.4 & 7.02 & 0.6 & 10.53 & 35.1 & 1.35 \\
\hline & & & & & & & & & & & 382.53 & 14.68 \\
\hline \multicolumn{13}{|l|}{ Rotifera } \\
\hline Brachionus caudatus & 2.4 & 42.11 & 0.4 & 7.02 & 1.4 & 24.56 & 0.6 & 10.53 & 0.4 & 7.02 & 91.24 & 3.50 \\
\hline B. dimidiatus & 0.6 & 10.53 & 1 & 17.54 & 0.8 & 14.04 & 0.8 & 14.04 & 1.2 & 21.05 & 67.2 & 2.58 \\
\hline B. falcatus & 0 & 0.00 & 0.8 & 14.04 & 0.4 & 7.02 & 0 & 0.00 & 0.2 & 3.51 & 14.57 & 0.56 \\
\hline B.calyciflorus & 0 & 0.00 & 0.2 & 3.51 & 0.6 & 10.53 & 0 & 0.00 & 0.6 & 10.53 & 24.57 & 0.94 \\
\hline Keratella serrulata & 0.2 & 3.51 & 1.4 & 24.56 & 0 & 0.00 & 0.4 & 7.02 & 0.4 & 7.02 & 42.11 & 1.62 \\
\hline K. cochlaris & 0.4 & 7.02 & 0 & 0.00 & 2 & 35.09 & 2.2 & 38.60 & 2.6 & 45.61 & 126.32 & 4.85 \\
\hline K. quadrenticus & 0.6 & 10.53 & 1 & 17.54 & 0.8 & 14.04 & 0.2 & 3.51 & 0.2 & 3.51 & 49.13 & 1.88 \\
\hline K. tropica & 0.4 & 7.02 & 0.8 & 14.04 & 0.8 & 14.04 & 3.8 & 66.67 & 0.6 & 10.53 & 112.3 & 4.31 \\
\hline K. valga & 0.4 & 7.02 & 0 & 0.00 & 1.8 & 31.58 & 1.6 & 28.07 & 1.6 & 28.07 & 94.74 & 3.63 \\
\hline \multirow[t]{2}{*}{ K. cruciformis } & 1.4 & 24.56 & 0.2 & 3.51 & 0.6 & 10.53 & 0.2 & 3.51 & 2.4 & 42.11 & 84.22 & 3.23 \\
\hline & & & & & & & & & & & 706.4 & 27.10 \\
\hline
\end{tabular}




\begin{tabular}{|c|c|c|c|c|c|c|c|c|c|c|c|c|}
\hline \multirow[t]{2}{*}{ Site / Species } & \multicolumn{2}{|r|}{$\mathbf{A}$} & \multicolumn{2}{|c|}{ B } & \multicolumn{2}{|c|}{$\mathbf{C}$} & \multicolumn{2}{|r|}{ D } & \multicolumn{2}{|c|}{$\bar{E}$} & \multirow[b]{2}{*}{$\begin{array}{l}\text { TFC } \\
\text { (Org/I) }\end{array}$} & \multirow[b]{2}{*}{$\begin{array}{l}\text { Frequency } \\
(\%)\end{array}$} \\
\hline & TC & $\begin{array}{l}\text { FC } \\
(\text { Org/I) }\end{array}$ & TC & $\begin{array}{l}\text { FC } \\
(\text { Org/I) }\end{array}$ & TC & $\begin{array}{l}\text { FC } \\
(\text { Org/I) }\end{array}$ & TC & $\begin{array}{l}\text { FC } \\
(\text { Org/I) }\end{array}$ & TC & $\begin{array}{l}\text { FC } \\
(\text { Org/I) }\end{array}$ & & \\
\hline \multicolumn{13}{|l|}{$\begin{array}{l}\text { CRUSTACEA } \\
\text { Cladocera }\end{array}$} \\
\hline Diaphanosoma sarsi & 0.2 & 3.51 & 0.2 & 3.51 & 0 & 0.00 & 0.4 & 7.02 & 0.2 & 3.51 & 17.55 & 0.67 \\
\hline Moina micrura & 0.2 & 3.51 & 2.2 & 38.60 & 2.8 & 49.12 & 1 & 17.54 & 0.4 & 7.02 & 115.79 & 4.44 \\
\hline Bosmina.longirostris & 3.9 & 68.42 & 2.6 & 45.61 & 2.4 & 42.11 & 1.8 & 31.58 & 3.6 & 63.16 & 250.88 & 9.62 \\
\hline B. pellucida & 0.2 & 3.51 & 0.4 & 7.02 & 0 & 0.00 & 1.2 & 21.05 & 0.2 & 3.51 & 35.09 & 1.35 \\
\hline B.freyi & 0.2 & 3.51 & 0 & 0.00 & 0 & 0.00 & 0.4 & 7.02 & 0 & 0.00 & 10.53 & 0.40 \\
\hline B. rostrum & 0 & 0.00 & 0.4 & 7.02 & 0.6 & 10.53 & 0 & 0.00 & 0.6 & 10.53 & 28.08 & 1.08 \\
\hline Daphnia pulex & 0.4 & 7.02 & 0.4 & 7.02 & 1.8 & 31.58 & 1.4 & 24.56 & 1.8 & 31.58 & 101.78 & 3.90 \\
\hline D. retrocurva & 0.2 & 3.51 & 1.6 & 28.07 & 1.6 & 28.07 & 0.2 & 3.51 & 0.6 & 10.53 & 73.69 & 2.83 \\
\hline Leptodora kindti & 0.2 & 3.51 & 0 & 0.00 & 0 & 0.00 & 0.6 & 10.53 & 0.2 & 3.51 & 17.55 & 0.67 \\
\hline Sida crytalina & 0 & 0.00 & 0.6 & 10.53 & 0.2 & 3.51 & 2.2 & 38.60 & 0 & 0.00 & $\begin{array}{l}52.64 \\
703.58\end{array}$ & $\begin{array}{l}2.02 \\
26.99\end{array}$ \\
\hline \multicolumn{13}{|l|}{ Calanoida } \\
\hline Tropodiaptomus incognitus & 2.4 & 42.11 & 1.6 & 28.07 & 2.4 & 42.11 & 1.8 & 31.58 & 2 & 35.09 & 178.96 & 6.87 \\
\hline Tropediaptomus lateralis & 0.4 & 7.02 & 3 & 52.63 & 0.8 & 14.04 & 2 & 35.09 & 0.8 & 14.04 & 122.82 & 4.71 \\
\hline Leptodiaptomus sicilis & 0 & 0.00 & 0.8 & 14.04 & 1.2 & 21.05 & 0.4 & 7.02 & 1.6 & 28.07 & 70.18 & 2.69 \\
\hline Nauplius larva & 0 & 0.00 & 0.2 & 3.51 & 0.6 & 10.53 & 0.4 & 7.02 & 0 & 0.00 & $\begin{array}{l}21.06 \\
\mathbf{3 9 3 . 0 2}\end{array}$ & $\begin{array}{l}0.81 \\
\mathbf{1 5 . 0 8}\end{array}$ \\
\hline \multicolumn{13}{|l|}{ Cylopoida } \\
\hline Mesocylops spp. & 0.2 & 3.51 & 0.6 & 10.53 & 1.8 & 31.58 & 0.6 & 10.53 & 1.2 & 21.05 & 77.2 & 2.96 \\
\hline Tropocylops confinis & 0 & 0.00 & 0 & 0.00 & 1 & 17.54 & 0 & 0.00 & 0 & 0.00 & 17.54 & 0.67 \\
\hline Neocylops affinis & 0.2 & 3.51 & 0.8 & 14.04 & 0 & 0.00 & 2.2 & 38.60 & 0.2 & 3.51 & 59.66 & 2.29 \\
\hline Afrocyclops monody & 0 & 0.00 & 0 & 0.00 & 0.2 & 3.51 & 0.2 & 3.51 & 0 & 0.00 & 7.02 & 0.27 \\
\hline Macrocyclops spp. & 0 & 0.00 & 1.2 & 21.05 & 0 & 0.00 & 0.4 & 7.02 & 1.2 & 21.05 & 49.12 & 1.88 \\
\hline $\begin{array}{l}\text { Mesocyclops leukarti } \\
\text { Total (Org/L) }\end{array}$ & 0.4 & $\begin{array}{l}7.02 \\
\mathbf{3 8 4 . 3 1}\end{array}$ & 2.6 & $\begin{array}{l}45.61 \\
\mathbf{4 8 7 . 7 5}\end{array}$ & 3 & $\begin{array}{l}52.63 \\
\mathbf{5 6 1 . 4 6}\end{array}$ & 3.4 & $\begin{array}{l}59.65 \\
\mathbf{6 3 1 . 6 4}\end{array}$ & 2.6 & $\begin{array}{l}45.61 \\
\mathbf{5 6 1 . 4 4}\end{array}$ & $\begin{array}{l}210.52 \\
\mathbf{4 2 1 . 0 6} \\
\mathbf{2 6 0 6 . 5 8} \\
\end{array}$ & $\begin{array}{l}8.08 \\
16.15 \\
100\end{array}$ \\
\hline
\end{tabular}

KEY: TC $=$ Total count, $\mathrm{FC}=$ Fauna count, $\mathrm{TFC}=$ Total fauna count 
Table 2: Mean Monthly Values of Physicochemical Parameters and Zooplankton Density in Jakara Dam (March, 2013- February, 2014)

\begin{tabular}{|c|c|c|c|c|c|}
\hline Sampling Sites & $\mathrm{A}$ & B & C & $\mathrm{D}$ & $\mathrm{E}$ \\
\hline Temperature ( & 25.3 & 23.9 & 24.0 & 24.0 & 25.3 \\
\hline Secchi disk Transparency $(\mathrm{cm})$ & 10.7 & 54.7 & 57.9 & 38.6 & 33.4 \\
\hline Dissolved Oxygen $(\mathrm{mg} / \mathrm{l})$ & 4.5 & 3.3 & 3.7 & 4.9 & 3.9 \\
\hline $\begin{array}{l}\text { Biochemical Oxygen Demand } \\
(\mathrm{mg} / \mathrm{l})\end{array}$ & 2.5 & 1.7 & 1.5 & 2.4 & 2.1 \\
\hline Electrical Conductivity $(\mu \mathrm{S} / \mathrm{cm})$ & 856.7 & 818.1 & 817.9 & 844.5 & 838.2 \\
\hline $\mathrm{pH}$ & 7.2 & 7.8 & 7.8 & 7.8 & 7.7 \\
\hline Nitrate (mg/l) & 23.8 & 16.2 & 14.3 & 21.1 & 19.5 \\
\hline Phosphate ( $\mathrm{mg} / \mathrm{l})$ & 15.8 & 13.3 & 12.5 & 14.6 & 14.3 \\
\hline Zooplankton Density (Org/l) & 12.7 & 36.8 & 42.4 & 47.7 & 40.0 \\
\hline
\end{tabular}

Table 3: Mean Values of Physico-Chemical Parameters in Jakara Dam During Wet and Dry Seasons (March, 2013- February, 2014)

\begin{tabular}{lll}
\hline Parameters / Season & Wet season & Dry season \\
\hline Temperature () & 24.9 & 22.8 \\
Secchi disk transparency $(\mathrm{cm})$ & 41.5 & 37.9 \\
Dissolved oxygen $(\mathrm{mg} / \mathrm{l})$ & 3.3 & 2.3 \\
$\mathrm{BOD}(\mathrm{mg} / \mathrm{l})$ & 1.8 & 1.2 \\
$\mathrm{EC}(\mu \mathrm{S} / \mathrm{cm})$ & 747.5 & 880.2 \\
$\mathrm{pH}$ & 7.7 & 7.9 \\
Nitrate $(\mathrm{mg} / \mathrm{l})$ & 11.3 & 28.9 \\
Phosphate $(\mathrm{mg} / \mathrm{l})$ & 7.8 & 22.2 \\
\hline
\end{tabular}

Table 4: Zooplankton Structure and Biological Indices at Five Sampling sites in Jakara Dam (March, 2013- February, 2014)

\begin{tabular}{llllll}
\hline Biological Index /Sites & A & B & C & D & E \\
\hline Zooplankton Total Count (Org/I) & 383.31 & 487.75 & 561.46 & 631.64 & 561.44 \\
Shannon-Wieners Index (H) & 2.77 & 3.03 & 3.1 & 3.13 & 3.09 \\
Evenness Index (E) & 0.47 & 0.49 & 0.49 & 0.49 & 0.49 \\
Simpson's Index (Ds) & 0.09 & 0.057 & 0.050 & 0.059 & 0.056 \\
& & & & & \\
\hline
\end{tabular}

Table 5: Zooplankton Fauna Composition during Wet and Dry season in Jakara Dam (March, 2013February, 2014)

\begin{tabular}{|c|c|c|c|c|}
\hline \multirow{2}{*}{ Taxon } & \multirow{2}{*}{$\begin{array}{l}\text { Wet Season } \\
\text { Total (Org/I) }\end{array}$} & \multirow[b]{2}{*}{$\begin{array}{c}\text { Frequency } \\
(\%)\end{array}$} & \multicolumn{2}{|c|}{ Dry Season } \\
\hline & & & Total(Org/I) & $\begin{array}{l}\text { Frequency } \\
(\%)\end{array}$ \\
\hline Protozoa & 161.31 & 19.99 & 157.77 & 15.54 \\
\hline Rotifera & 196.36 & 24.34 & 329.70 & 32.48 \\
\hline Cladocera & 214.00 & 26.53 & 267.82 & 26.39 \\
\hline Calanoida & 161.44 & 20.01 & 172.03 & 16.95 \\
\hline Cyclopoida & 73.69 & 9.13 & 87.70 & 8.64 \\
\hline Total (Org/L) & 806.8 & 100 & 1015.02 & 100 \\
\hline
\end{tabular}

Table 6: Zooplankton Structure And Biological Indices of Water Quality during Wet and Dry Season (March, 2013- February, 2014)

\begin{tabular}{lcc}
\hline \multicolumn{1}{c}{ Biological Indices / Season } & Wet Season & Dry Season \\
\hline Zooplankton total fauna count(Org/I) & 747.19 & 878.31 \\
Shannon- Weiner Index & 3.03 & 3.01 \\
Evenness Index & 0.46 & 0.44 \\
Simpson's Index & 0.056 & 0.057
\end{tabular}




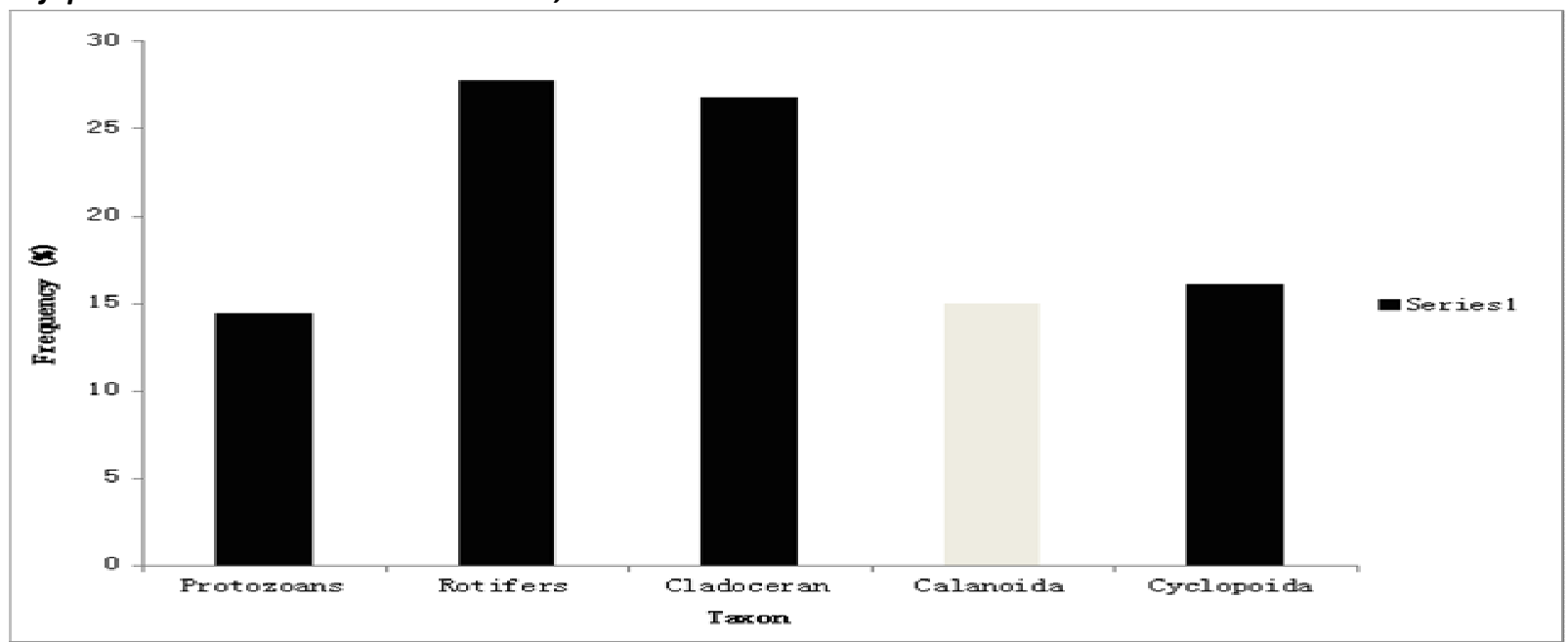

Figure 2: Frequency of Zooplankton Against Taxon in Jakara Dam (March, 2013- February, 2014)

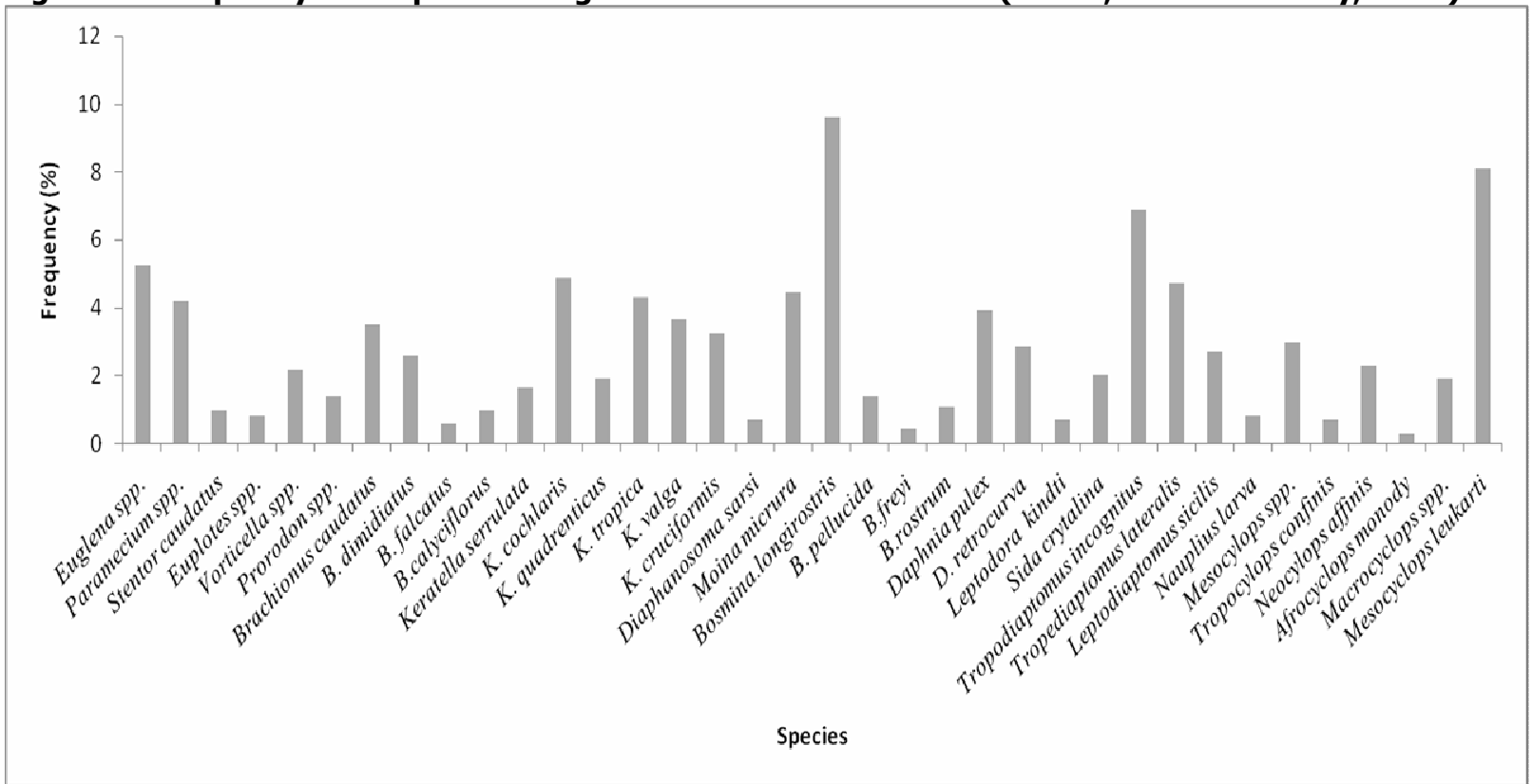

Figure 3: Frequency Against Zooplankton Species (March, 2013- February, 2014)

\section{RESULTS AND DISCUSSIONS}

The result obtained showed that zooplankton highest species richness was recorded at site $D(631.64 \mathrm{Org} / \mathrm{l})$ followed by sites E, C, and B with 561.44 Org/l, 561.46 Org/l, and $487.75 \mathrm{Org} / \mathrm{l}$ respectively. Site A had the least number of species (384.21 Org/l). Zooplankton species richness according to taxa showed highest value of 10 species of Rotifers, Cladocerans 10, Protozoa 6, Cyclopoida 6, and Calanoida 4 species. Bosmina longirostris showed highest distribution and abundance of $250.88 \mathrm{Org} / \mathrm{l}$, Afrocyclops monodi had the least of $7.02 \mathrm{Org} / \mathrm{l}$ (Table 1and Figure 3).

Rotifers are being considered as the most important soft bodied invertebrates. They play a significant role in aquatic food chain and thereby constitute an important food items to fish. The composition of rotifers communities responds to environmental factors and therefore can be used as biological indicator of trophic condition of aquatic ecosystem (Huchtchinson, 1967). In the present study, rotifers had $27.10 \%$ of the total zooplankton species identified (Table 1 and Fig. 2). This agrees with the findings of Lamai and Kolo (2003) in Rabiu et al. (2011) who studied the zooplankton of Dan-Zaria Dam and observed 40 taxa dominated by the rotifers. Similar observation was made by Thirupathaniah et al.(2011). The present study is in agreement with the findings of Imoobe and Adeyinka (2010) who stated that the zooplankton community structure was dominated by numerous species of rotifers in tropical forest river.

Cladocera are popularly called 'water flea' and prefers to live in deep water and constitute a major item in food chain and energy transformation (Uttangi, 2001). During the present study 10 species were recorded which formed $26.99 \%$ of the total collection (Table 1 and Figure 2). 
Bajopas Volume 8 Number 2 December, 2015

Protozoa are an important food source for micro invertebrates thus, the ecological role of protozoa in the transfer of bacterial and algal production to successive trophic levels is important. As predators, they prey upon unicellular or filamentous algae, bacteria and micro fungi. They control bacteria population (Alcamo and Warner 2009). Six (6) species of protozoa were recorded which made up $14.44 \%$. Euglena spp were $142 \mathrm{Org} / \mathrm{l}$ out of the total count of 397.4 Org/l (Table 1and Figure 2).

Cyclopoida and Calanoida had $16.14 \%$ and $15.00 \%$ respectively (Table 1 and Figure 2). The total number of zooplankton species in the dry season (878.31 Org/l) was greater than the values obtained in the wet season 747.19 Org/l (Table 5 and 6).

From the calculated result, the values of ShannonWeiner's, Evenness index and Simpson's index were between $2.7-3.13,0.47-0.49$ and $0.09-0.54$ respectively (Table 4). Shannon-Weiner's and Evenness indices were high in the wet season than in the dry season. Simpson's index is higher in the dry season than in the wet season (Table 6). This result was similar with the findings of Thirupathaniah et al. (2001). The relationship between species diversity and pollution status of aquatic ecosystem are classified as follows; $>3$ = clean water, $1-3=$ moderately polluted $<1$ = heavily polluted (William et al., 2002). This indicated that the Dam is moderately polluted.

The mean monthly range of temperature was 25.323.9 (Table 2). These values were within the National Environmental Standard and Regulation Enforcement Agency (NESREA) (1991) emission standard of 30 for discharge of effluents into river (Ibrahim, 2009). The mean values of temperature in the rainy season were 24.9 and 22.8 and in the dry season (Table 3). Differences in water temperature may be due to the timing of collection and influence of season (Adeniji, 1993). Similar reasons were given by Ibrahim (2009).

Transparency enables the sun rays to penetrate to a certain depth, enabling photosynthetic flora to perform productive activities, which is very important in aquatic ecosystems (Huchtchinson, 1967). The annual mean of transparency was low at site $A(10.7 \mathrm{~cm})$ and high at site $C(57.9 \mathrm{~cm})$ (Table 2$)$. The mean transparency was slightly higher in the rainy season (Table 3 ).

Dissolved Oxygen is one of the most important parameters that indicate water purity. It is essential in maintaining a variety of forms of biological life in water. According to Department for International Development (DFID) (1999), DO provides a broad indicator of water quality and that DO concentration in unpolluted water is normally about $8-10 \mathrm{mg} / \mathrm{l}$ at 25 . The annual mean DO of $4.5 \mathrm{mg} / \mathrm{l}$ was the highest recorded at site $A$, with lowest value of $3.3 \mathrm{mg} / \mathrm{l}$ observed at site $B$ (Table 2 ). The highest monthly mean of $3.9 \mathrm{mg} / \mathrm{l}$ was recorded in the month of May in the early rainy season and lowest of $2.4 \mathrm{mg} / \mathrm{l}$ in late rainy season. In the wet season, the DO mean value was $3.3 \mathrm{mg} / \mathrm{L}$ while the value of $2.3 \mathrm{mg} / \mathrm{l}$ was recorded in the dry season (Table 3 ). This result was in agreement with the values of DO observed by Imam (2010) in the same water. Ibrahim (2009) stated that river that contained higher level of inorganic and organic pollutants tents to have low dissolved oxygen.

The annual mean values of BOD ranged between 1.7 and $2.5 \mathrm{mg} / \mathrm{l}$ (Table 2). Low values of BOD were obtained in the months of dry season (Table 3). This agreed with the finding of Awanda (1987) that studied the effect of industrial effluents on biota of River Kaduna. He reported that BOD was higher in the dry season than the rainy season during the period of oxygen consumption by decomposers (bacteria and fungi) on biogenic materials. Based on classification of aquatic bodies, unpolluted water BOD $<1.0 \mathrm{mg} / \mathrm{l}$, moderately polluted $\mathrm{BOD}<10.00 \mathrm{mg} / \mathrm{l}$ and heavily polluted BOD > 10.00mg/l (Maria, 1983). BOD above 1 $\mathrm{mg} / \mathrm{l}$ is associated with waste water contamination (UNESCO, 1991). The result of electrical conductivity showed that annual monthly mean value was highest at site $A\left(856.7 \mu \mathrm{Scm}^{-1)}\right.$ and lowest $\left(817.9 \mu \mathrm{Scm}^{-1}\right)$ at site C (Table 2). The higher electrical conductivity observed at site $A$ may be attributed to the intensive irrigation farming because of fertilizer application, such activity was lacking at site $\mathrm{C}$, which is the mid-point of the water. This agrees with the observation made by Sebastain et al. (2004) that the higher the ionic concentrations in water the greater the conductivity. The average mean value of EC in the dry season was slightly greater than the value obtained in the rainy season (Table 3). This could have been due to the high level of nutrient in the site.

During the present study, highest mean $\mathrm{pH}$ was recorded at site $A$ (7.9) and lowest at site $E$ (7.7) (Table 7). The result fall within the acceptable limit of $6.5-8.5$ and 6 - 9 recommended by the WHO (1999) and (NESREA) (1991) respectively for inland and drinking water.

The concentration of nutrient in water body is strongly influenced by the nature of the sediment. Wetzel (2001) reported that the rate of phosphorus released into water body can be doubled when the sediments are frequently disturbed. The highest annual mean value of nitrate was recorded at site $A(23.8 \mathrm{mg} / \mathrm{I})$ and lowest at site $C(14.3 \mathrm{mg} / \mathrm{l})$. Consequently, the mean value of phosphate obtained at site $A$ of $15.8 \mathrm{mg} / \mathrm{l}$ was the highest and lowest at site $C$ was $12.5 \mathrm{mg} / \mathrm{l}$ (Table 2 ). The values of nitrate obtained from this study were below WHO and FEPA tolerance limit of $45 \mathrm{mg} / \mathrm{l}$ for drinking water (Mahre et al. 2007). The mean values of nutrients obtained in the dry season were significantly higher than the respective values recorded in the months of the rainy season (Table 3 ). This could have been attributed to the dry season irrigation farming and concentration of these nutrients due to evaporation. This was in agreement with the findings of Mohammad and Saminu (2012) that studied the effect of physico- chemical factors on seasonal dynamics in Nguru Lake.In the wet months of the rainy season, Pearson's Coefficient analysis showed that there was positive relationship between temperature and nitrate and BOD at $\mathrm{P}<0.05$, likewise between $\mathrm{DO}$ and phytoplankton and zooplankton, BOD and nitrate and phosphate at $\mathrm{P}<0.01$. 
Bajopas Volume 8 Number 2 December, 2015

Similarly, negative correlation was recorded between Secchi disk transparency and BOD at $\mathrm{P}<0.05$, and Secchi disk transparency and phosphate at $\mathrm{P}<0.01$ were observed. In the dry season, positive correlation existed between secchi disk transparency and zooplankton, DO versus phosphate at $\mathrm{P}<0.01$. Likewise between $\mathrm{DO}$ versus $\mathrm{BOD}, \mathrm{BOD}$ versus nitrate and phosphate, nitrate and phosphate at $\mathrm{P}<0.01$, also negative correlation existed between zooplankton and nitrate, temperature and EC and nitrate at $\mathrm{P}<0.01$ so also between zooplankton and phosphate, secchi disk transparency and $\mathrm{pH}$ at $\mathrm{P}<0.05$.

\section{CONCLUSION}

Zooplankton diversity and abundance could be used as an important tool in monitoring changes in Jakara Dam. During the period of this study, site A had very low secchi disk transparency and high level of nitrate and phosphate in the whole sampling sites. This is due to the suspended matter resulting from the runoff from

\section{REFERENCES}

Abdullahi, B.A. (1990): The Effect of Temperature on Size and Development in Three species of Benthic Copepods, Hydrobiologia (Berlin) 67: $215-297$.

Adeniji, H.A. (1993): Studies of Some Physico-chemical Factors and Heavy Metals in Jakara Reservoir in Kano state. NIFFR Ann. Rep. 136-140.

Alcamo, E. and Warner, J.M. (2009): Schaum's Outline Microbiology, McGraw Hill Professional, New York. p144

APHA (2005): Standard Methods for Examination of Water and Wastewater, 21 ${ }^{\text {st }}$ Edition; Eaton, A.D, Clescer, L.S, Rice, E.N. and Greenberg, A.E Port City Press, Baltimore, US.

Awanda, C.O.A. (1987): Effect of Industrial Effluents on the Biota of River Kaduna. Ph.D Thesis. Department of Biological Sciences, A.B.U Zaria. Pp 285.

Baker, J.M. (1976): Biological Monitoring -Principles, Methods and Difficulties In Marine Ecology and Oil Pollution. (Ed) J.M. Baker, the Institute of Petroleum, Great Britain 41-54.

Boyd, C.E and Frobish, L.Y. (1998): Water Quality for Ponds Aquaculture. Birmingham Publishing Co., Birminghsm, UK. 5-90.

Bryan, J.R. (1974): A Winkler's Procedure for Oxygen Measurement; Journal of Experimental Microbial Ecology 21: 191-197.

DFID (1999): A Simple Methodology for Water Quality Monitoring. (Pearce GR, Chaudhry Ghulumed)Department For International Development, Willing ford: 234-289.

Durand, J.R and Lévéque, C. (1980) : Floré et Fauné aquatiques de la afrique; Sahela Soudanienne.

Duwa, M.R. and Oyeyi T.T. (2009): The Role of Jakara Dam in the Transmission of Schistosomiasis: Bayero Journal of Pure and Applied Science. Bayero University Kano 2 (1): 58 - 63. the surrounding farmland that uses the water for irrigation, and fishing activities especially at site A where these activities was high. Zooplankton as bioindicators of both pollution and trophic condition of water system.

\section{RECOMMENDATIONS}

In a bid to providing safe water for domestic and industrial uses, water treatment plant should be provided to help in water treatment especially at site A (Bella community) of this research area.

Government should provide the farmers with modern means of irrigation, for this will help to control and regulate agricultural activities around the area, hence checking entry and exit of water through water channels.

The need for government to provide a means for treating effluents from the source (origin) cannot be over emphasized

Goswani, S.C. (2004): Zooplankton Methodology: Collection and Identification; National Institute of Oceanography Dona Paula, Goa403004. 1-14.

Hanna Instrument (2004): Instruction Manual. Hi. 146 Portable Water Proof Microprocessor Dissolved Oxygen, pH/EC/TDS meters. Hanna Instrument.

Hutchinson, G.E. (1967): A Treatise on Limnology. Introduction to Lake Biology and Limnoplankton. Vol. 2 Wiley, New York, pp 1115.

Ibrahim, S. (2009): A Survey of Zooplankton Diversity of Challawa River, Kano and Evaluation of some of its Physico - Chemical conditions. Bayero University Journal of Pure and Applied Science, 2 (1): $19-26$.

Imam, T.S. (2011): Monitoring Water Quality using Zooplanktonic Fauna as Bioindicators at Wassai Reservoir, Kano State, Northern Nigeria. Biological and Environmental Sciences Journal for the, Tropics, 8(1):219-225.

Imam, T.S. (2012): Application of Biological Diversity Indexing in the Water Quality Monitoring and Pollution Assessment. Biological and Environmental Sciences Journal for the Tropics. 9 (2). ISSN 0794-9057.

Imam, T.S. (2010): Aspect of Ecology and Biomonitoring of Heavy Metals Associated with Industrial Pollution in Bampai- Jakara Catchment Basin Kano State Nigeria; PhD Progress Seminar Presented at Biological Sciences Department, Bayero University Kano on $24^{\text {th }}$ February 2010.

Imoobe, T.O. and Adeyinka, M.L. (2010): Zooplanktonbased Assessment of the Tropical State of a Tropical Forest River. International Journal of Fisheries and Aquaculture, 2(2):64-70.

Lead Technologies Inc (2002): SPSS for Windows, SPSS, SPSS Version 15. US. 
Lamai, S.L. and Kolo, R.J. (2003): Biodiversity and Abundance of Fish and Plankton of Dan- Zaria Dam, Niger State, Nigeria Journal of Aquatic Science, 18: (2) 141- 150.

Lynne, M. W. (2004): Practical Guide to Identifying Freshwater Crustacean Zooplankton. Cooperative Freshwater Ecology Unit, Department of Biology, Laurentian UniversityOntario, Canada. Cooperative Freshwater Ecology Unit $2^{\text {nd }}$ edition.

Mahre, M.Y., Akan J.C., Moses, E.A. and Ogugbuaja V.O. (2007): Pollution Indicators in river Kaduna, kaduna state, Nigeria. Trends in Applied Sciences Research, 2:304-311.

Maria, D. (1983): Sewage Treatment in Hot Climate, John Wiley and Sons, Toronto.

Mohammad, M.A. and Saminu, M.Y. (2012): A Water Quality and Phytoplankton of Salanta River Kano, Nigeria: .Journal of Biological Science and Bioconservation 4 (1) 22-77

NESREA (1991): National Environmental Standard and Regulation Enforcement Agency (Effluent limitation). Regulation of 1991 National Environmental Standard and Regulation Enforcement Agency Lagos, Nigeria. Fef. No. S. 18

Rabiu, M., Balarabe, M.L. and Indabawa, I.I. (2011): The Influence of Physico-Chemical Parameters on the Zooplankton Distribution of kussalla Reservior, Kano State. Bayero University Journal of Pure and Applied Science, 4 (1): 87-90. 374-385.

Sebastain, F., Josepht, H. and Alvaro, M. (2004): The Effect of Nitrates Concentration on Conductivity in four Water Sources. Colegio Franklin Delano Roosevelt. 4-8.

Scourfield, D.J. and Harding. J.P. (1958):A Key to the British Fresh Water Cladocera with Notes on Their Ecology; Fresh Water Biological Association Scientific Publication No. $52^{\text {nd }}$ edition. 1-15.

Shield, R.J. and Green, J.D. (1995): Rotifera recorded from New Zealand; N.Z.J Zool.
Shield, R.J. (1995): A Guide to Identification of Rotifers, Cladocerans and Copepods from Australian inland waters; the Murray-Darling Fresh Water Research Centre Identification Guide No. 3.

Simpsons, C.D. and Weaver, W. (1963): The Mathematical Theory of Community. University Press, Urbana.

Singh, R. and Singh, S.P. (2002): Ecology of Polluted Water, Volume 2.A.P.H Publishing Corporation New Delhi.

Soberron, J., Rodriguez, P. and Vazquezdominguez, A. (2002): Implications of Hierarchical Structure of Biodiversity for Development of Ecological Indicators Suitable Use. Ambio, 29: 136-142.

Thirupathaniah, M., Samatha, C.H., and Samamaih, C.H. (2001): Diversity of Zooplankton in Freshwater Lake of Kamalapur, Karimnagar district. India. The ecoscan 5 (1):85-87.

UNESCO (1991): Volunteer Lake Monitoring. Government protection. EPA 440/4-91-002 US.

Uttangi, J.C. (2001): Conservation and Management Strategy for the Water Fowls of Minor Irrigation Tank Habit and Management, Daya Publication, New Delhi, India 179-221.

Wetzel, R.G. (2001): Limnology, Lake and River Ecosystems ( $3^{\text {rd }}$ edn) Academic press.San Francisco.

Welcomme, R.L. (1985):River Fisheries. FAO fish tech.pap. (262): p.330

William, E.S., William, G.K. and Anthony, R.B. (2002): Biotic Index Guide. Pennysylvania State University.

WHO (1999): Limits for Effluents Discharge into Surface Waters. World Health Organization, Geneva. $\mathrm{CH}$.

WRECA (1974). Hydrological Survey of North - East Kano State Planning Programme. 